\title{
The relationships between ripeness, vigour and methods of harvest of winter wheat grain
}

\author{
RIAD ZAIDAN
}

Institute of Plant Biology, Agricultural-Technical Academy, 10-957 Olsztyn-Kortowo, Poland (Received: July 9, 1981).

\begin{abstract}
The purpose of our vigour tests was to reveal the relationships betwen the viability of wheat grains, their germination rate and capacity and respiration intensity. The wheat grain was collected in two ways. The first grain was removed from the ears immediately after harvest (denoted as series A) and the second grain was left in the ears at room temperature for two weeks after harvest (denoted as series B). This grain was harvested at three stages of ripeness (milk, wax and full ripeness). Our results demonstrated that wheat grain at the full ripeness stage was of better biological quality than that at milk and wax ripeness stages. The grain of series B from all ripeness stages showed a higher viability than the grain of series A. On the other hand, grains at milk, wax and full repeness in series B were more mature than those at milk, wax and full ripeness in series A. Therefore it can be concluded probably that the embryo and endosperm in the latter grains were much more developed and much organic matter was passing from the stalk to the seeds when they were kept in the ear for two weeks after harvest.
\end{abstract}

\section{INTRODUCTION}

Agricultural productivity depends to a large extent on the quality of sown seeds (Woodstock 1969). Rapid and reliable laboratory methods for testing seed vigour are of potential benefit in two ways. Firstly they may inform whether to sow a given seed batch. Secondly they may indicate how to plant a batch of seed, how early, how densely etc. (Woodstock 1969).

The main shortcoming of seed quality tests in that they fail to provide all the information needed by wholesalers, distributors, farmers and others (Woods tock 1969). Many kinds of seed injury are not detected in conventional germination tests (Takayanagi and Murakami 1969). Seed dormancy interferes sometimes with laboratory testing. 
Seed vigour may be defined "as that condition of active good health and natural robustness in seeds which, upon planting, permits germination to proceed rapidly and to completion under a wide range of environmental conditions" (Woodstock 1973). In the present work physiological methods were used for measuring the vigour of grains, their growth potential (wheat grains from three stages of development) as well as germination rate and capacity, weight of grains, intensity of respiration (measured as rate of oxygen uptake) and length of seedlings roots and shoots. Also biochemical methods were used for estimation of the protein content of mitochondria.

It is very important for the physiologist who is interested in seed vigour to apply methods which are simple, cheap and provide results corresponding to field seedling emergence.

\section{MATERIAL AND METHODS}

Studies were carried out in 1979 on seeds of winter wheat (cv. Grana) collected in 1979. It was grow on the experimental fields of the Institute of Plant Biology of the Agricultural-Technical Academy in Olsztyn.

Seed material was collected in three stages of grain development: 1) during milk ripeness-20 days after anthesis; 2) during wax ripeness- 42 days after anthesis; 3) during full morphological ripeness (maturation stage) -56 days after anthesis.

The ears were divided into two parts, from one part grain was taken out directly after harvest and dried carefully at room temperature. These grains were denoted as series A. The second part of ears was kept for two weeks at room temperature. After this period the ears were threshed by machine and the grains were used for the experiments. These grains were denoted as series B. In this way six grain samples were obtained. About 3 months after the last grain sample had been collected the following analyses were performed: germination rate and capacity on moist filter paper placed in Petri dishes at constant temperature of $21 \mathrm{C}$.

Manometric estimation of respiratory intensity of all germinating grain samples (which germinated 4 days) with a Warburg apparatus at $25 \mathrm{C}$. The experiment was repeated twelve times.

Seedling growth was determinated as average roots and shoots lenght after 4 days of germination (total shoots and roots length divided by the number of seeds planted).

Mitochondria from wheat grain embroys were isolated by differential centrifugation, as described by Pomeroy (1974) for wheat seedlings. The composition of the media used. isolation and washing of mitochondria were essentially similar to those described by Ikuma (1970). The content of mitochondrial protein was measured by the biuret method (Layne 1957), using borine serum albumin as a standard. 


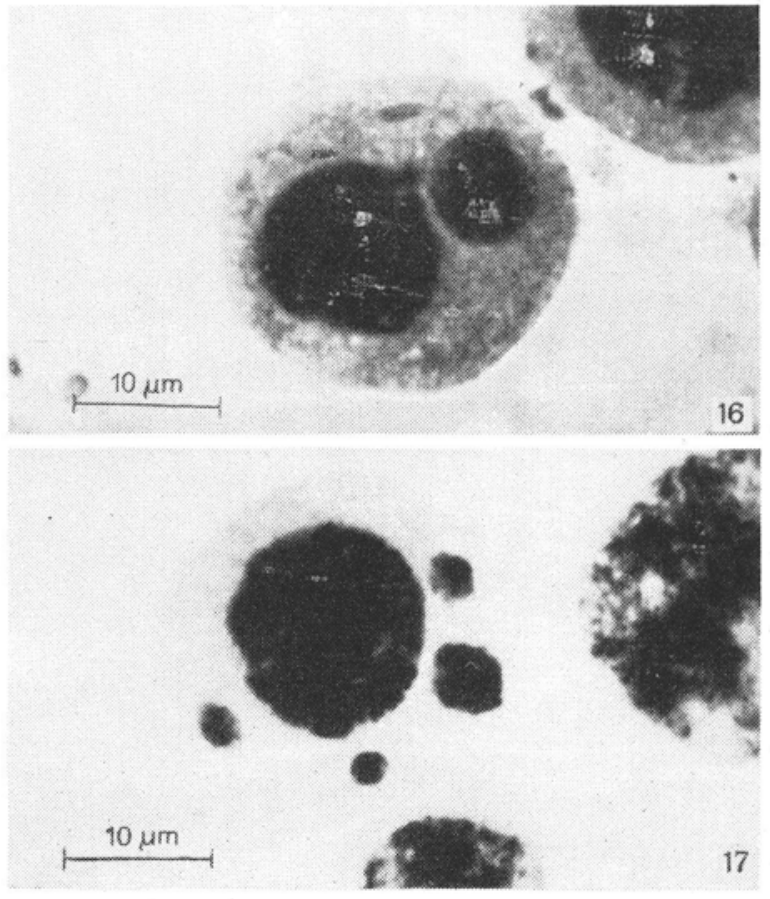

Fig. 16. Two-nucleate pollen grain

Fig. 17. Pollen grain with four micronuclei 
Embryos were separated from the endosperm by hand with a sectioning needle. After 4 days of germinarion, dry and fresh weight were determined by weighing before and after drying at $103^{\circ} \mathrm{C}$. The experiment was repeated three times.

\section{RESULTS AND DISCUSSION}

RELATIONSHIPS BETWEEN GERMINATION RATE AND CAPACITY. SHOOT AND ROOT LENGTH. O UPTAKE AND THE METHODS OF HARVEST

Growth characteristics of wheat grains related to germination rate and capacity are presented in Table 1 . Fully ripe grains harvested and stored in series A and B and grains from the wax ripeness stage (series B) had a greater germination rate and capacity than those in the other combination (milk in series A and B, and wax stages in series A). Grains collected during milk ripeness had the lowest germination rate and capacity. Embryo development was at this stage morphologically not completed and the endosperm of these grains did not accumulate enough food reserves (Abdul-Baki and Baker 1973, Grzesiuk and Kulka 1981). Grains of milk ripeness grew in about $50 \%$ abnormally.

\section{Table 1}

Germination rate and capacity of winter wheat grains; shoot and root lengths and $\mathrm{O}_{2}$ uptake after 4 days of germination at different stages of ripeness following two methods of hari est

\begin{tabular}{|l|c|c|c|c|c|c|}
\hline $\begin{array}{c}\text { Stages of } \\
\text { grain } \\
\text { det elopment }\end{array}$ & $\begin{array}{c}\text { Harvest } \\
\text { methods }\end{array}$ & $\begin{array}{c}\text { Rate of } \\
\text { germination } \\
\%\end{array}$ & $\begin{array}{c}\text { Capacity of } \\
\text { germination. } \\
\%\end{array}$ & $\begin{array}{c}\text { Mean shoot } \\
\text { lenght. } \\
\text { mm }\end{array}$ & $\begin{array}{c}\text { Mean root } \\
\text { lenght. } \\
\text { mm }\end{array}$ & $\begin{array}{c}\mathrm{O}_{2} \text { uptake in } \\
\mu \mathrm{l} / 100 \text { gra- } \\
\text { ins/1 min }\end{array}$ \\
\hline Milk stage & A & 30 & 43 & 5.56 & 2.5574 & 37.9470 \\
\hline Wax stage & B & 27 & 61 & 5.34 & 2.9893 & 55.2730 \\
\hline Full ripeness & A & 39 & 71 & 8.72 & 4.3120 & 39.9883 \\
stage & B & 79 & 95 & 24.02 & 2.7293 & 32.3468 \\
\hline
\end{tabular}

A grains remoed from the cars immediately after har est

B-grains kept in the ears at room temperature for 2 weeks after har est.

Confirmation of the above mentioned facts was obtained by measuring the length of shoots and roots of seedlings 4 days after the start of germination (Table 1). The smallest shoot and root lengths were noted for seedlings from grains collected during milk ripeness. The period of keeping grain in the ears after harvest (series B) had very little effect on the growth of seedlings. Seedlings from grains at wax ripeness exhibited medium growth, whereas the most intensively growing seedlings (shoot and root lengths) were recorded in the case of seedlings from grains collected at full ripeness (Table 1). 
The respiration rate of grains estimated after $96 \mathrm{~h}$ (Table 1) showed that grains at wax ripeness (B) exhibit the lowest oxygen uptake. Grains at milk ripeness (B) respirated like those at full ripeness. The grains at milk ripeness have simple reserve materials which are easily utilized by the respiratory apparatus, neither the formation of their embryos is not yet completed (Abdul-Baki and Baker 1973, Grzesiuk and Kulka 1961, Rejowski 1961). Grains at full ripeness have more complicated reserve materials than at wax and milk ripeness, which is not easily available to the respiratory apparatus. But the embryos from grains at full ripeness have a well developed respiratory apparatus (Abdul-Baki and Baker 1973. Bewley and Black 1978). Mitochondria of seeds at full ripeness have a highly organized membrane system reflecting high metabolic ability (Abdul-Baki and Baker 1973).

RELATIONSHIPS BETWEEN DRY FRESH WEIGHT. RESPIRATORY RATE. MITOCHONDRIAL PROTEIN CONTENT AND METHODS OF HARVEST

Dry and fresh weight of wheat seedlings after 4 days of germination are summarized in Table 2. The smallest dry and fresh weight were characterisitic for grains from milk stage (series A). Grains at milk and wax ripeness in series B had a higher dry and fresh weight than at milk and wax stages in series A. On the other hand the fresh and dry mass of growing germs depends also on the stage of grain ripeness and the methods of harvest. It is probable that the embryo and endosperm in this grain was much more developed and much organic matter passed from the stalk to the seeds when they were kept in the ear for two weeks after harvest. On the other hand. at milk and wax ripeness in series B were more mature than the grains at milk and wax ripeness in series $\mathrm{A}$. This difference could not be

Table 2

Dry and fresh weight of wheat winter grains, intensity of respiration and content of mitochondrial protein after 4 days of germination of seeds at different stages of ripeness following two methods of hariest

\begin{tabular}{|c|c|c|c|c|c|c|}
\hline $\begin{array}{c}\text { Stage of } \\
\text { grain } \\
\text { development }\end{array}$ & $\begin{array}{l}\text { Hariest } \\
\text { methods }\end{array}$ & $\begin{array}{l}\text { Dry weight of } \\
100 \text { grains, } \\
\mathrm{g}\end{array}$ & $\begin{array}{c}\text { Fresh weight } \\
\text { of } 100 \\
\text { grains, g }\end{array}$ & $\begin{array}{cc}\mu \mathrm{ll} & \mathrm{O}_{2} / \mathrm{lg} \\
\text { dry } & \text { weight }\end{array}$ & $\begin{array}{c}\mu \mathrm{l} \mathrm{O}_{2} / \mathrm{lg} \\
\text { fresh weight }\end{array}$ & $\begin{array}{c}\text { The centent } \\
\text { of mitochon- } \\
\text { drial protein, } \\
\text { mg/ } 100 \\
\text { embryos }\end{array}$ \\
\hline Milk stage & $\begin{array}{l}\text { A } \\
\text { B }\end{array}$ & $\begin{array}{l}2.3923 \\
2.4461\end{array}$ & $\begin{array}{c}5.4520 \\
9.6423\end{array}$ & $\begin{array}{l}27.6499 \\
40.3950\end{array}$ & $\begin{array}{l}7.8532 \\
9.4848\end{array}$ & $\begin{array}{l}0.37558 \\
0.44734\end{array}$ \\
\hline Wax stage & $\begin{array}{l}\text { A } \\
\text { B }\end{array}$ & $\begin{array}{l}3.4475 \\
3.6137\end{array}$ & $\begin{array}{l}9.4033 \\
9.7138\end{array}$ & $\begin{array}{l}17.3735 \\
10.5496\end{array}$ & $\begin{array}{l}5.7103 \\
4.6362\end{array}$ & $\begin{array}{l}0.53413 \\
0.55517\end{array}$ \\
\hline $\begin{array}{c}\text { Full ripeness } \\
\text { stage }\end{array}$ & $\begin{array}{l}\text { A } \\
\text { B }\end{array}$ & $\begin{array}{l}3.9559 \\
3.6641\end{array}$ & $\begin{array}{r}9.5620 \\
10.4211\end{array}$ & $\begin{array}{l}16.5459 \\
15.3945\end{array}$ & $\begin{array}{l}7.2314 \\
6.6043\end{array}$ & $\begin{array}{l}0.60000 \\
0.68679\end{array}$ \\
\hline
\end{tabular}

A. B-see Tablc 
noticed in fully ripe grains. Growth of the seedlings in the initial stage of germination was more rapid if the grains were kept in the ears (series B) (Table 2). As demonstrated in Table 2 the fresh and dry mass of germs in riper grains was greater.

Results obtained for respiration intensity (per $1 \mathrm{~g}$ dry and $1 \mathrm{~g}$ fresh weight) were related oppositely with the stages of development (Table 2). They were highest at milk stage and lowest at the full ripeness. We see clearly that the respiratory rate of milk stage grains (series B) is higher than that of grains at milk stage in series A, wax stage in series A, B and like the respiratory rate of grains at full ripeness (series A, B). These results confirm our assumption as to the high respiration activity of milk stage grains from series B (Table 1) also expressed by many authors (Abdul-Baki and Baker 1973, Bewley and Black 1978, Grzesiuk and Kulka 1981): the grains at milk ripeness have accumulated simple reserve materials in the endosperms which are easily utilized by the respiratory apparatus.

Mitochondrial protein content from fully ripe grains (series B) was highest and in the case of milk stage (series A) was lowest (Table 2). As seen in Table 2 the riper grain was characterized by a higher mitochondrial protein content. Furthermore, the content of mitochondrial protein depended also on the methods of harvest (series A and B).

More rapidly growing seedlings contain larger amounts of mitochondrial protein (McDaniel 1973). Seedling vigour can thus be related to the quantity of mitochondria (McDaniel 1969). Although differences in physiological development between seedlings are reflected in different respiratory rates, the specific respiratory activity per unit of mitochondrial protein has been found to remain constant (McDaniel 1969).

In the present work we have studied the relationships between viability and vigour of grains of winter wheat (cv. Grana) harvested and stored in two ways, i.e. (direct - series A, seed removed from the ears immediatly after the harvest; and indirect-series B, seed kept in the ears for two weeks after harvest) and the intensity of respiration.

Stages of grain ripeness and the methods of grain harvest influenced the seed vigour (Tables 1 and 2). Fully ripe wheat grains had better qualities than grains at milk and wax stage. As already reported (McDaniel 1973), seedlings produced from heavier fully ripe seeds grew better and had a higher respiratory rate. The more rapidly growing seedlings contained a larger amount of mitochondrial protein. sufficient to account for the increased respiration rates of seedlings produced from heavier seeds in contrast to those from lighter ones.

In our biochemical and physiological tests, grain from fully ripe seeds showed the highest vigour. The grains from fully ripe seeds had a mature embryonic axis and accumulated in the endosperm enough food reserves (Grzesiuk 1971, Abdul-Baki and Baker 1973, Bewley and Black 1978). 
Other authors (Abdul-Baki and Baker 1973) have already shown that grains from fully ripe seeds have a good functional and structural systems. The endosperm of these grains also has enough food reserves to suppor growth and development of the embryonic axis until a photosynthesizing. autotrophic plant is estabilished (Ching 1973. Grzesiuk 1967. Bewley and Black 1978. Grzesiuk and Kulka 1981). This period is very important because the embryonic exis still grows and forms the new plant (Abdul-Baki and Baker 1973. Bewley and Black 1978). Therefore, we haie decided to study the major changes in seed tissues from the milk to the full ripeness stage pointing out those changes which might brought vigour loss.

\section{REFERENCES}

Abdul-Baki A. A.. Baker J. E.. 1973. Are changes in cellular organelles or membranes related to vigor loss in seeds? Seed Sci. 1: 89-127.

Bewley J. D.. Black M.. 1978. Physiology and Biochemistry of seeds in Relation to Germination. In: Development. Germination and Growth. Vol. 1. Springer-Verlag. Berlin-Heidelberg-New York.

Ching T. M.. 1973. Biochemical aspects of seed vigor. Seed Sci. 1: 73-89.

Grzesiuk S.. 1967. Fizjologiczne właściwości dojrzewajacych nasion. ich wartość siewna. przechowywanie oraz wpływ na rozwój roślin w polu. Biul. IHAR 1-2: 7-140.

Grzesiuk S.. 1971. Fizjologiczne i biochemiczne przemiany w dojrzewajacych nasionach. Zesz. Probl. Post. Nauk Rol. 113: 29-68.

Grzesiuk S...Kulka K.. 1981. Rozwój i dojrzewanie nasion. PWRiL. Warszawa.

Ikuma H.. 1970. Necessary conditions for isolations of tightly coupled higher plant mitochondria. Plant Physiol. 45: 773-781.

Layne E.. 1957. Spectrophotometric and turbidimetric methods for measuring proteins. In: Methods in Enzymology. Vol. 3. S.P. Coldwick. N.O. Kaplan (eds.). Academic Press. New York. pp. 447-454.

McDaniel R.G.. 1969. Relationships of seed weight. seedling vigor and mitochondrial metabolism in barley. Crop. Sci. 9: 823-827.

McDaniel R. G.. 1973. Genetic factors influencing seed vigor-biochemistry of heterosis. Seed Sci. 1: 25-51.

Pomeroy M.K.. 1974. Studies on the respiratory properties of mitochondria isolated from developing winter wheat seedlings. Plant. Physiol. 53: 653-658.

Rejowski A.. 1961. Fizjologia i biochemia dojrzewajacego ziarna pszenicy. Cz. 1. Morfologia rozwoju oraz fizjologiczne właściwości dojrzewajacego ziarna. Roczn. Nauk Rol. ser. A 85: 293-305.

Takayanagi K.. Murakami K.. 1969. New method of seed iability test with exudates from seed. Proc. Int. Seed Test. Ass. 34: 243-252.

Woodstock L. W.. 1969. Biochemical tests for seed vigor. Proc. Int. Seed Test. Ass. 34: 253-263.

Woodstock L. W.. 1973. Physiological and biochemical tests for seed igor. Seed Sci. 1: 127-161. 
Zależności między stopniem dojrzalości, sposobem zbioru $i$ wigorem ziarna przenicy ozimej odmiany Grana

\section{Streszczenie}

Celem podjętej pracy było zbadanie zależności pomiędzy żywotnościa ziarna pszenicy. zebranego systemem jedno- i dwufazowym (seria A i B) w fazie dojrzałości mlecznej. woskowej i pełnej. a zdolnościa jego kiełkowania i intensywnościa procesów oddechowych. Wykazano. że ziarno pszenicy zebrane w iazie dojrzałości pełnej charakteryzowało się znacznie wyższa wartościa biologiczna w porównaiu z ziarnem zebrnym w fazie dojrzałości mlecznej i woskowej. Wszystkie partie ziarna zebrane systemem dwufazowym (system B). wykazywały wysoka żywotność. Charakteryzowły się one ponadto wyższym wigorem w stosunku do ziarna zebranego systemem jednofazowym (seria A). Przypuszcza się. że powodem był dalszy rozwój zarodka i bielma zachodzacy podczas dosychania ziarna w kłosach. 